Research:

\title{
THE AFFECT OF THE SIZE OF COMMISSIONERS BOARD AND THE SIZE OF THE COMPANY REGARDING THE ENVIRONMENTAL DISCLOSURE
}

\author{
By: \\ Desy Anggrarini and Eindye Taufiq
}

\begin{abstract}
This research aims to examine and to prove empirically the size of Commissioners Board and the size of the Company regarding the Environmental Disclosure. It has been identifying the manufacturing companies registered in the Indonesia Stock Exchange Market as the samples. Sampling technique has applied purposive sampling method. Sampling is 92 from 149 manufacturing companies registered in the Indonesia Stock Exchange Market in 2014. This research has applied secondary data obtained from website www.idx.co.id. Hypothesis analysis of this research has applied the analysis of Multiple Linier Regression using SPSS 21 with a significant level of 5\%. The result of this research has indicated that the size of a commissioners board has not affected the environmental disclosure, but the size of a company has unsignificantly affected the environmental disclosure.
\end{abstract}

Keywords : The size of a commissioners board, the size of a company, and the environmental disclosure.

\section{INTRODUCTION}

The development of an industrial sector has been a part of the National Development process to increase the economy development. The industries have given either positive or negative impact for the society. The development of the industrial sectors has been creating bad impact which is the pollution of the environment refers to many problems have been coming up. The level of the environmental contamination in Indonesia has been occurred due to a high industrial activity. It has been explained that many companies in Indonesia have obtained a negative opinion refers to the unfinished environmental management, environment damaged, due to lack intention of the company to take care the environmental conversion.

The Government regulations have made the companies to be aware of the importance of the environmental management. The companies could be able to show their social responsibility through the Environmental Disclosure.

An Environmental disclosure is about the information disclosure regarding the company responsibility to the environment stated on the financial reporting (Paramitha \& Rohmnan, 2014). The Environmental Disclosure has been an important thing to identify the environmental disclosure in the annual report of a company, so that, the society could monitor the acitivity of the company in relation with their corporate social responsibility (Effendi, Uzliawati, Yulianto, 2012).

The company that has been implementing and executing the environmental disclosure will be obtaining a lot of benefits, lifting up the company brand image, obtaining social operational license, reducing business risk, getting more accessibilities of operational networking, opening broad market opportunity, fixing a good relationship with stakeholders and regulatory, improving the productivity of employees as well as their enthusiasm, and having the opportunity to receive the reward (Untung 2009).

The size of the commissioners board has been a mechanism to control and to provide the direction and guidance to manage the company or management. (Rahadja and Pratama, 2013).

The company with a quite big size of the commissioners board has inclined to disclose more social information than others (Darlis, et, al, 2009). By having an independent commissioners board, in general, they have had a better broad supervision to the management, so, they could 
avoid the probability of cheating occurred in the management in providing the financial reporting or the environmental disclosure of the company (Ariningtika \& Kiswara, 2013)

The effect of the environment has been depending on the characteristics of the company. The characteristics of the company have been affecting the degradation of the environmental quality, eq, the bigger company the bigger impact of the environment will happen. (Suhardjanto, 2010). Big companies have bigger public demand rather than smaller companies. The reason is big companies have little production information cost related to their disclosure.

Table 1. Fenomena Environmental Disclosure

\begin{tabular}{|c|c|c|c|c|c|}
\hline No. & Company & Damages & Impact & Total Aset & $\begin{array}{c}\text { Total of } \\
\text { commissioners } \\
\text { board }\end{array}$ \\
\hline 1. & & $\begin{array}{l}\text { Almost all the } \\
\text { green forest } \\
\text { which was } \\
\text { very thick } \\
\text { before } \\
\text { surrounding } \\
\text { Toba Lake has } \\
\text { been } \\
\text { destroyed and } \\
\text { planted by } \\
\text { eucalyptus } \\
\text { instead of. }\end{array}$ & $\begin{array}{l}\text { The companies that } \\
\text { have been } \\
\text { destroying the } \\
\text { green forest would } \\
\text { jeopardize Toba } \\
\text { Lake beauty. Based } \\
\text { on the Indonesian } \\
\text { Farmers Union } \\
\text { (SPI), the } \\
\text { shallowness of } \\
\text { Toba lake has been } \\
\text { happened, the } \\
\text { green forest has } \\
\text { been destroyed due } \\
\text { to the function of } \\
\text { the forest to keep } \\
\text { natural water has } \\
\text { almost gone, } \\
\text { biological resources } \\
\text { both animal and } \\
\text { plantation } \\
\text { disappeared and } \\
\text { Asahan river has } \\
\text { been contaminated } \\
\text { reflecting to a lot of } \\
\text { fish died. }\end{array}$ & $\begin{array}{l}4.106 .790 .000 \\
(>10 \text { billions }= \\
\text { huge company) }\end{array}$ & 4 persons \\
\hline 2. & $\begin{array}{l}\text { PT Indah } \\
\text { Kiat Pulp } \\
\text { \& Paper }\end{array}$ & $\begin{array}{l}\text { Burning the } \\
\text { green forest to } \\
\text { get the raw } \\
\text { material and to } \\
\text { throw away } \\
\text { the waste to } \\
\text { the river. }\end{array}$ & $\begin{array}{l}\text { Smoke producing } \\
\text { and the water of } \\
\text { ciujung river has } \\
\text { been becoming } \\
\text { black and spreading } \\
\text { the unpleasant } \\
\text { smell in hot season. }\end{array}$ & $\begin{array}{l}81.073 .679 .00 \\
0 \\
(>10 \text { billions }= \\
\text { huge company }\end{array}$ & 7 persons \\
\hline 3. & $\begin{array}{l}\text { PT } \\
\text { Krakatau } \\
\text { Posco }\end{array}$ & $\begin{array}{l}\text { Pollution } \\
\text { because of the } \\
\text { dust of } \\
\text { production. }\end{array}$ & $\begin{array}{l}\text { The people } \\
\text { surrounding the } \\
\text { company has been } \\
\text { suffering of skin } \\
\text { itching and skin } \\
\text { burning because of } \\
\text { the dust. }\end{array}$ & $\begin{array}{l}32.313 .988 .00 \\
0 \\
>10 \text { billions }= \\
\text { huge company }\end{array}$ & 6 persons \\
\hline
\end{tabular}

Sources : analyzed from various resources. 
This research is related to the previous research done by Effendi, Uzliawati and Yulianto (2012). The differences of this research and the previous one are relating to the sampling and period of time applied. Effendi, Uzliawati, \& Yulianto (2012) applied the samples of the manufacturing companies registered in the Indonesia Stock Exchange (BEI) period of 2008, 2009, 2010 and 2010. But this research has been applied the samples of all the manufacturing companies registered in BEl for the period of 2014.

\section{LITERATURES REVIEW AND HYPOTHESIS DEVELOPMENT.}

The disclosure of the environmental responsibilities.

The Environmental Disclosure is the disclosure of an environment relating to the living space.. (Suhardjanto, 2010). Suhardjanto (2010) identified that the environment refers to pollution control, prevention and recovery of the environmental damage, natural conservation and others related to the living space.

Two characteristics of corporate environmental disclosure responsibility. Suhardjanto \& Miranti (2009) indicated that the related disclosure based on the standard requirements which is required / regulated / mandatory disclosure. Mandatory disclosure is the minimum disclosure required by the Authority Institution (Government, IAI, or BAPEPAM-LK). According to the mandatory disclosure, the company has not been disclosing the related requirement would be forced to disclose. Voluntary disclosure is when a company has been disclosing the requirement voluntarily. The company declaring voluntarily the social responsibility has been considering about the cost and benefit refers to the requirements of the stakeholders and to the increasing of the company image.

\section{The Size of the Commissioners Board.}

Acts no, 40 year of 2007 chapter 1 article 6 defined that the Board of the Commissioners is a part of the company to supervise generally and specifically which is in accordance with the regulations of the company and to advise the board of the directors. The board of the commissioners is obliged to supervise and to give a direction or advice to the board of the directors.

Board of the commissioners is a mechanism tool to supervise and to give a direction to the management of the company (Pratama \& Rahardja, 2013). Akhtarudin, et,al (2009) in Effendi et,al (2012) described that board of the commissioners is the size of the commissioners board to execute a better monitoring activity. Rusdianto (2013) determined that the bigger members of the commissioners board the easier controlling and monitoring the CEO could be done.

\section{The size of the company.}

The size of the company is the variable describing a varied quantity of the disclosure in the company annual report. (Paramitha \& Rohman, 2014). Rusdianto (2013) determined that the size of the company could be affecting the information disclosure more regarding the company financial reporting. In general it explains that a huge company would be able to disclose more information than small company.

The measurement of the size of a company is a kind of scale classifying the company refers to total assets, log e, share value and other aspects, the bigger assets of a company, the bigger company will be (Hartono 2010).

\section{Hypothesis Evolvement regarding Effect of the Size of Board of the Commissioners upon the Environmental Disclosure.}

The Commissioners Board is a part of the company which is in charge of supervising or monitoring and giving an advice collectively to the board of directors. The Commissioners Board is going to strengthen the effectiveness of the monitoring. In relation with the size of the commissioners board, Rusdianto (2013) described that the more member of the board of commissioners the easier effective way to control and monitor the CEO would be.

The company having a bigger size of the commissioners board tends to disclose the environmental information more proper than the other ones, (Darlis, et.al. 2009). In order to 
determine the size of the commissioners board, it is depending on the total of the member of the commissioners board (Cunningham, 2000 in Darlis, et, al, 2009).

The research done by Effendi, et, al (201), Pratama \& Rahardha (2013), describing that the size of the commissioners board has not affected the environmental disclosure. The effect of the size of the commissioners board upon the environmental disclosure could be identified in the research done by Darlis, et, al. Their research has identified that the size of the commissioners board has had a negative effect upon the environmental disclosure.

$\mathrm{H}_{1}$ : The size of the commissioners board has affected negatively to the environmental disclosure.

\section{The Effect of the Size of a Company upon the Environmental Disclosure}

The size of a company could be measured refers to total assets, total sale, average of total sales and total assets. The research done by Suhardjanto (2010) determined that the size of a company has been affecting the environmental disclosure. Big company will be performing a lot of activities affecting the environment.

It is in compliance with the theory of stakeholder describing that stakeholders have an opportunity to control the company resources. The research done by a bigger organization has a lot of stakeholders to be satisfied to keep the company running well.

Cowen et al (1987) in Suhardjanto (2010), huge companies are being underpressured to disclose their activities in order to legitimate their business since huge companies have been performing more activities, stronger influences to the society, and many shareholders who are fully aware of the environmental program done by the company, refers to the annual report which provides an efficient information to communicate it with their stakeholders accordingly. Therefore, bigger companies have more willingness to declare the information about their environment disclosure properly.

It is in accordance with the research done by Galani et,al (2011), Suttipun \& Stanton (2012), Effendi et. al. (2012), Effendi \& Uzliawati (2012), Akrout \& Othman (2013), Paramitha \& Rohman (2014), Aulia \& Agustina (2015) determined that the size of a company has been affecting the environmental disclosure.

$\mathrm{H}_{2}$ : The size of a company has a positive effect to the Environmental Disclosure.

\section{RESEARCH METHOD}

\section{Variables Measurement.}

Measuring the Environmental Disclosure as a dependent variable has been applying EIR index (Indonesia Environmental Reporting) refers to the previous research done by Suhardjanto, Tower, and Brown (2007) (with the value of $0-34,98)$ The size of the Commissioners Board $\left(X_{1}\right)$ is measured by applying the indicator of total members of the commissioners board. The scale data is a ratio scale. The size of a company $\left(\mathrm{X}_{2}\right)$ is measured by applying the natural logarithm upon the total assets of the company.

\section{Sampling and Population Selection}

The population which will be selected as the objects of the research are all manufacturing companies which registered in the Indonesia Stock Exchange in 2014. The reason why the researcher has chosen the manufacturing companies is because they are being considered to be able to represent the industrial companies where the manufacturing companies are the root-cause mostly of the environmental damage due to their waste.

Samples in this research are all the manufacturing companies registered in the Indonesia Stock Exchange in 2014 which have been in compliance with the criteria of the samples identified. Criteria of sampling selection is purposive sampling as follows: (1) All the manufacturing companies registered in the Indonesia Stock Exchange (BEI) have issued and published their annual report audited by the Indonesia Stock Exchange in 2014; (2) All the manufacturing companies are using rupiah currency (Rp) in 2014; (3) All the manufacturing companies have disclosed the company environmental information which is in compliance with the criteria of scoring index (IER). 


\section{DESCRIPTION AND RESULT OF THE RESEARCH}

\section{Result of the Research}

Result of the classical assumption analysis has identified normal data distribution.

Multicolonizer Test has indicated that none of dependent variable has a tolerance value less than $10 \%$ and VIF more than 10 , hence, it could be concluded that controlled variables in this research have not identified any multicolonizer symptom within the independent variables.

Result of heteroskedastisity has indicated that the scatter of data points are on the upper and lower of 0 at $Y$ line and a clear pattern has not been identified which is heteroskedastisity has not happened.

$\mathrm{F}$ calculated value is 3.798 and the significance of this research is 0.026 using $\mathrm{F}$ distribution table and significant level 0.05 resulting $F$ table 3.10 , but $F$ calculated 13.746 , it explains that $F$ calculated $>\mathrm{F}$ table refers to a significant level $0.000<0.05$,it concludes that the variable of the size of the commissioners board and the size of company have a significant affect simultaneously upon the variable of the environmental disclosure.

The size of the commissioners board has $T$ calculated value of 0.480 and $T$ table 1.66216 refers to $\mathrm{T}$ calculated $<\mathrm{T}$ table and the significant value $0.632>0.05$. It has explained that the size of the commissioners board has not been affecting the environmental disclosure. The size of the company has $\mathrm{T}$ calculated 1.750 and $\mathrm{T}$ table 1.66216 refers to $\mathrm{T}$ calculated $>\mathrm{T}$ table and significant value $0.084>0.05$. It explains that the variable of the size of company has not affected the environmental disclosure.

\section{Description of the Affect of the size of the Commissioners Board upon the environmental disclosure.}

Result of the multiple regression test upon the variable of the size of the commissioners board has been applying the comparison between the size of the commissioners board and the total member of the commissioners board has an unsignificant effect to the environmental disclosure. This result is in compliance with the research done by Effendi, Uzliawati and Yulianto (2012) dan Pratama and Rahadja (2013) indicated that the size of the commissioners board has not affected the environmental disclosure. Otherwise, this research is different to the research done by Darlis, Zirman and Zulmi (2009) determined that the size of the commissioners board has a significant effect to the environmental disclosure.

The reasons why the size of commissioners board has not affected the environmental disclosure due to the tasks and responsibility of the commissioners board as follows; monitoring the company policy and management, advising the board of directors, responsible for the losses of the company and the bankruptcy of the company due to their lack of monitoring or advising. So that, the commissioners board has been focusing more to the financial aspects. Board of directors has been monitoring the social and environmental aspects instead of other aspects. The environmental aspect has not been managed accordingly because, the increasing of green customers are not quite high and the government involvement is not maximum.

\section{The affect of the size of a company upon the environmental disclosure.}

Multiple regression test result of the variable of the size of company has been applying the company total assets determining that there has been affecting the environmental disclosure unsignificantly.

This result has been in compliance with the result done by Anggraini (2006, Ariningtika and Kiswara (2006). The company environmental disclosure has not been affected by the size of the company, either huge or small company probably has not performed the environmental disclosure obviously. It happens because the company has not encountered yet the efficacy of the environmental disclosure. It explains that the environmental disclosure has not been considered as an obligation for the company that could give a future positive effect. Based on the stakeholder theory, the performance of the company environmental disclosure has been decided by the company stakeholders mostly.

Nevertheless, this research has not been in compliance with theory which is the stakeholders have not insisted on the company to perform the environmental disclosure so that the company are not aware of the environmental matters as well as the environmental disclosure. 


\section{The Research Limitation.}

The environmental disclosure topics have not been analyzed yet very often, so that the researcher has encountered some difficulties to collect the related references and theory of the research. Hence, the related company has not yet implemented the index which is in compliance with the research criteria of the environmental disclosure, so that, the researcher has encountered some difficulties to interprete the report of the environmental management prepared by the company since there is only a few of the companies providing the environmental disclosure in the annual report. Furthermore the company has not provided a complete data.

\section{Conclusion}

The objective of this research is to examine and to discover empirically regarding the affect of the size of the commissioners board and the size of company upon the environmental disclosure refers to the manufacturing companies registered in the Indonesia Stock Exchange (BEI) in 2014. In compliance with the data analysis which has been done before, it is concluded that the size of commissioners board has not affected significantly to the environmental disclosure as well as the size of the company has not been affecting significantly to the environmental disclosure.

\section{Suggestions}

The result of this research is expected to be a reliable reference for the government to strengthen the regulations about the environmental responsibility of the company which is to be implemented accordingly. This research is expected to be able to give a benefit for the company in the future which is the positive effects of the company refers to the environmental disclosure responsibility as the good information resources for the investors having a willingness to invest their capital considering the related company has been concerned about the environmental safety and respected to the applicable regulations obviously.

\section{LITERATURE}

Agoes, S., \& Ardana, I. C. (2009). Etika Bisnis dan Profesi Tantangan Membangun Manusia Seutuhnya. Jakarta: Salemba Empat.

Agustina, L., \& Aulia, F. Z. (2015). Pengaruh Karakteristik Perusahaan, Kinerja Lingkungan, dan Liputan Media terhadap Environmental Disclosure. Accounting Analysis Journal, Vol. 4, no. 3, hlm. 1-8.

Anggrarini, R. R. (2006). Pengungkapan Informasi Sosial dan Faktor-Faktor yang Mempengaruhi Pengungkapan Informasi Sosial dalam Laporan Keuangan Tahunan (Studi Empiris pada Perusahaan-Perusahaan yang terdaftar Bursa Efek Jakarta). Simposium Nasional Akuntansi IX.

Ariningtika, P., \& Kiswara, E. (2013). Pengaruh Praktik Tata Kelola Perusahaan yang Baik terhadap Pengungkapan Lingkungan Perusahaan. Diponegoro Journal of Accounting, Vol. 2, no. 2, hlm. 1-11.

Azheri, B. (2011). Corporate Social Responsibility: dari Voluntary Menjadi Mandatory, Jakarta: PT Raja Grafindo Persada.

Bursa Efek Indonesia. (2016). Laporan Keuangan Tahunan (Annual Report) dan Laporan $\begin{array}{llll}\text { Keuangan } & \text { Diakses } & 22 & \text { Februari }\end{array}$ http://www.idx.co.id/beranda/perusahaantercatat/laporankeuangandantahunan.aspx.

Effendi, B., Uzliawati, L., \& Yulianto, A. S. (2012). Pengaruh Dewan Komisaris terhadap Environmental Disclosure pada Perusahaan Manufaktur yang Listing di BEI tahun 20082011. Simposium Nasional Akuntansi XV. 
Effendi, R., Sayekti, Y., \& Wijayanti, R. R. (2012). Faktor-Faktor yang Mempengaruhi Tingkat Pengungkapan Tanggung Jawab Lingkungan dalam Laporan Tahunan. Jurnal Ekonomi Akuntansi dan Manajemen, Vol. 10, no. 2, hlm. 19-32.

Galani, D., Gravas, E., \& Stavropoulos, A. (2011). The Relation Between Firm Size and Environmental Disclosure. International Conference on Applied Economics. hlm. 179-186.

Ghozali, I. (2013). Aplikasi Analisis Multivariate dengan Program IBM SPSS 21 Update PLS Regresi. Semarang: Badan Penerbit Universitas Diponegoro.

Harahap, S. S. (2013). Teori Akuntansi. Jakarta: PT Raja Grafindo Persada.

Karo-Karo, A. S. (2015). SPI Desak Pemerintah Evaluasi Izin Toba Pulp Lestari Diakses 16 Mei 2016. http://www.mongabay.co.id/2015/02/04/spi-desak-pemerintah-evaluasi-izin-toba-pulplestari/.

Kementerian Perdagangan Republik Indonesia 2009, Peraturan Menteri Perdagangan Republik Indonesia Nomor 46/M-DAG/PER/9/2009 tentang Perubahan atas Peraturan Menteri Perdagangan Republik Indonesia Nomor 36/M-DAG/PER/9/2007 tentang Penerbitan Surat Izin Usaha Perdagangan, Kementerian Perdagangan Republik Indonesia, Jakarta.

Lako. (2011). Dekonstruksi CSR dan Reformasi Paradigma Bisnis \& Akuntansi. Jakarta: Erlangga.

Paramitha, B. W., \& Rohman, A. (2014). Pengaruh Karakteristik Perusahaan terhadap Environmental Disclosure. Diponegoro Journal of Accounting, Vol. 3, no. 3, hlm. 1-11.

Purwanti, A., \& Prawironegoro, D. (2013). Akuntansi Manajemen. Jakarta: Mitra Wacana Media.

Rahardja, A. G. P. (2013). Pengaruh Good Corporate Governance dan Kinerja Lingkungan terhadap Pengungkapan Lingkungan. Diponegoro Journal of Accounting, Vol. 2, no. 3, hlm. 1-14.

Rusdianto, U. (2013). CSR Communications a Framework for PR Practitioner. Yogyakarta: Graha IImu.

Sabar, K. (2014). Jejak Lingkungan Selembar Kertas, Diakses 16 Mei 2016. http://www.walhi.or.id/jejak-lingkungan-selembar-kertas.html.

Santoso, S. (2015). Menguasai Statistik Parametik Konsep dan Aplikasi dengan SPSS. Jakarta, PT. Elex Media Komputindo.

Sekaran, U. (2009). Research Methods for Business. Jakarta: Salemba Empat.

Sembiring, E. R. (2005). Karakteristik Perusahaan dan Pengungkapan Tanggung Jawab Sosial: Study Empiris pada Perusahaan yang Tercatat di Bursa Efek Jakarta. Simposium Nasional Akuntansi VIII.

Sugiyono. (2010). Metode Penelitian Pendidikan. Bandung: Alfabeta.

Suhardjanto, D. (2010). Corporate Governance, Karakteristik Perusahaan dan Environmental Disclosure. Jurnal Akuntansi dan Bisnis, Vol. 6, no. 1, hlm. 39-69.

Sungkawa, R. (2016). Kantor Lingkungan Hidup Ancam PT SNU Ditutup, setelah Dua Kali Ditegur Tak Juga Diindahkan, Diakses 23 Maret 2016. http://jabar.pojoksatu.id/sukabumi/2016/01/22/kantor-lingkungan-hidup-ancam-pt-snuditutup-setelah-dua-kali-ditegur-tak-juga-diindahkan/.

Desy Anggrarini and Eindye Taufiq: The Affect of The Size of Commissioners Board and The Size of The Company Regarding The Environmental Disclosure 
Suttipun, M., \& Stanton, P. (2012). Determinants of Environmental Disclosure in Thai Corporate Annual Reports. International Journal of Accounting and Financial Reporting, Vol. 2, No. 1, HIm. 99-115.

Suwardjono. (2010). Teori Akuntansi : Perekayasaan Pelaporan Keuangan. Yogyakarta: BPFE.

Takin, Z. (2015). Limbah Debu Besi Masih Cemari Pemukiman, Warga Ancam PT Krakatau Posco, Diakses 16 Mei 2016. http://www.beritacilegon.co.id/kota-cilegon/limbah-debu-besi-masihcemari-pemukiman-warga-ancam-pt-krakatau-posco.

Untung, H. B. (2009). Corporate Social Responsibility. Jakarta: Sinar Grafik. 